\title{
DADOS CIENTÍFICOS E A SOCIEDADE: REFLEXÕES SOBRE ALGUMAS CRENDICES PATRIMONIAIS*
}

\author{
*Conferência proferida pelo Prof. Dr. Diego Lemos \\ Ribeiro", junto à mesa "Comunicação e Educação \\ Patrimonial: o diálogo entre os dados científicos e \\ a sociedade", no evento RedeArq', que ocorreu \\ no dia 16 de fevereiro de 2017 (Joinville - SC) ${ }^{3}$.
}

Bom dia a todos e a todas. Meu nome é Diego, como foi falado e, de partida, eu queria agradecer muitíssimo a oportunidade de estar aqui conversando com vocês, revendo antigos amigos, fazendo novos, enfim. Está sendo um aprendizado muito grande participar deste evento, e, inclusive, isso reverberou diretamente no próprio trabalho que passo a apresentar.

Ontem, nós tivemos várias discussões riquíssimas e apresentações bastante provocativas. Isso incitou uma série de questões que me fizeram voltar ao hotel e dizer: "Não, eu tenho de rever minha apresentação por completo". Eu havia feito uma apresentação em moldes mais formais e burocráticos e optei agora por uma apresentação um pouco menos formal e mais palatável, mas sem que ela perdesse seu peso teórico.

Por motivos diversos - isso é muito engraçado sinalizar - , eu venho me afastando da Arqueologia. Muito porque eu venho investindo meus esforços em museus na zona rural e isso tem me propiciado uma série de reflexões. No entanto, por algum motivo também cosmológico, a Arqueologia não me deixa em paz; ela volta e meia me pega novamente, e esta proposta da Rede Arq, inclusive, está sendo de fundamental importância para eu voltar, talvez, para as minhas origens e começar a rever a Arqueologia.

\footnotetext{
${ }^{1}$ Professor adjunto do curso de Bacharelado em Museologia - Departamento de Museologia da Universidade Federal de Pelotas (UFPel).

${ }^{2} \mathrm{O}$ projeto RedeArq - Encontro de Museus de Arqueologia foi um evento científico que propôs ampliar o diálogo e reflexão sobre a gestão, a pesquisa e a difusão do patrimônio arqueológico nas instituições museológicas. O projeto foi contemplado no Edital Pró-eventos da Fundação de Amparo à Pesquisa e Inovação do Estado de Santa Catarina (Projeto Proeventos 3 - FAPESC 1375/2016). A programação de conferência, mesas-redondas e apresentações reuniu representantes de museus de diversas cidades e regiões para a formação de rede de museus de arqueologia. O RedeArq foi um projeto da pesquisadora Roberta Meyer Miranda da Veiga, com apoio e participação da equipe técnica do Museu Arqueológico de Sambaqui de Joinville (MASJ). O evento também integrou programação de eventos científicos que a instituição desenvolveu em 2017, ano que o MASJ completou 45 anos. O RedeArq tem anuência e apoio do MASJ e da Fundação Cultural de Joinville.

${ }^{3}$ Transcrição e adaptação realizadas por Caroline Pontes Ramos, estudante de Letras da Universidade Estadual de Campinas (UNICAMP). Revisão por Prof. Dr. Frederic M. C. Pouget.

\begin{tabular}{|l|l|l|l|l|l|l}
\hline (C) Rev. Arqueologia Pública & Campinas, SP & v.11 & n.2 & p. 264 & Novembro/2017 & ISSN 2237-8294
\end{tabular}
}




\section{Revista de Arqueologia Pública}

Bom, com base nas conversas que ocorreram ontem, eu fiquei refletindo: até que ponto o modelo que nós temos hoje de preservação do patrimônio - e não só patrimônio arqueológico - não é o modelo de certa forma arcaico que a gente precisa repensar? As fotografias a seguir mostram um pouco disso:
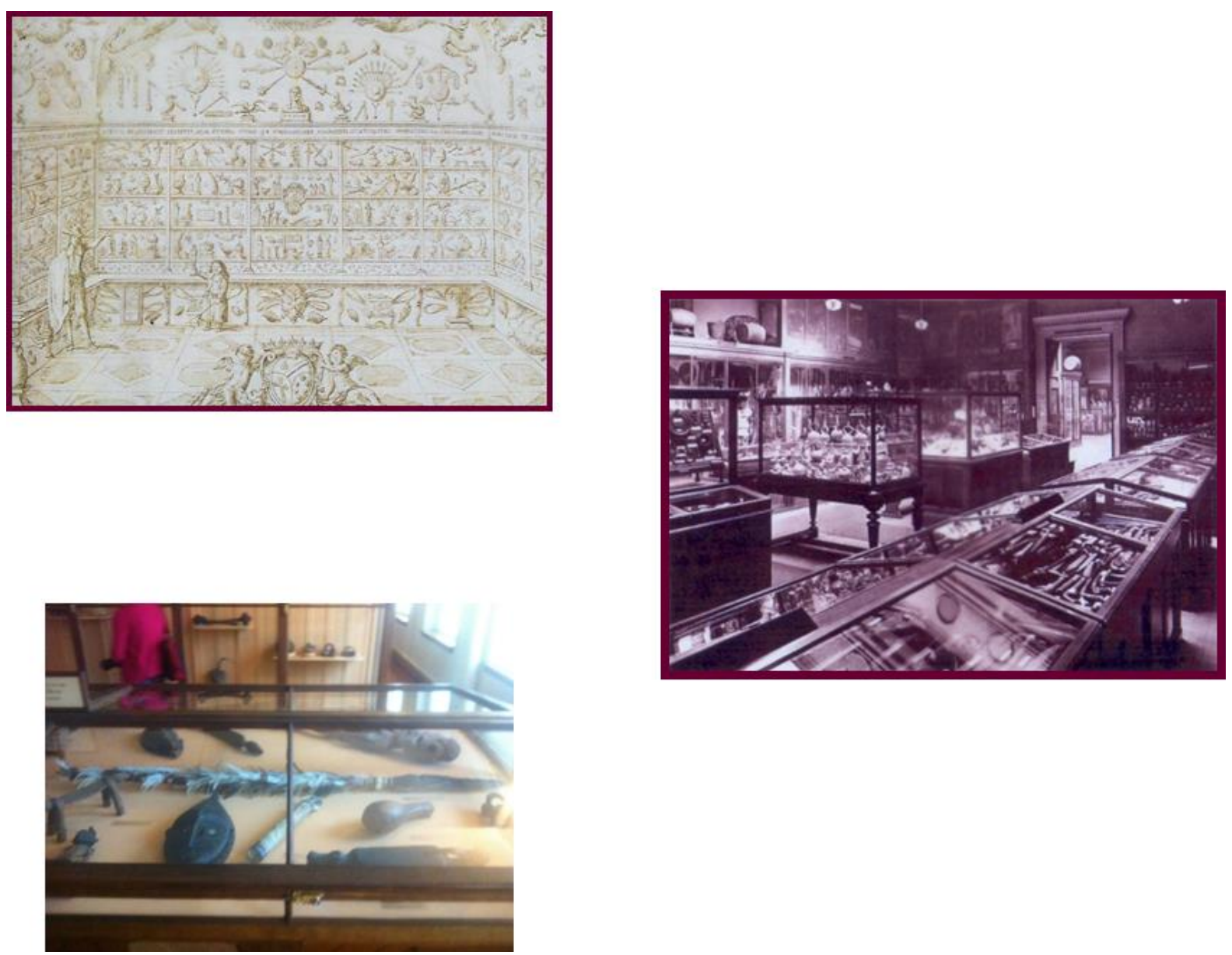

Fonte: com exceção da segunda fotografia à esquerda, produzida pelo autor, as demais foram retiradas da Internet.

Na primeira imagem, à esquerda, temos um gabinete de curiosidades do século XVII. Nele encontramos um amontoado de coisas, feitas pela humanidade e pela natureza, mais ou menos organizadas (ou desorganizadas, do ponto de vista atual) em um espaço feito para vislumbrar o "outro": o "outro" ausente, distante... O "outro" desconhecido.

$\mathrm{Na}$ imagem à direita, vemos o Museu Britânico, já do século $\mathrm{XX}$, com uma série de artefatos trancafiados em vitrines, como se ali estivessem sepultados. É uma profusão de objetos também servindo para a estupefação, para o exótico, para o raro e para o mostruário. 
Na última imagem, o Peabody Museum. Este museu, sediado em Harvard, é um dos primeiros de História Natural dos Estados Unidos, cuja exposição, pelo menos em parte, redunda em mostruários de objetos raros, exóticos e distantes no espaço e no tempo.

Bom, o que aproxima e o que afasta esses tempos? O que aproxima é que nós estamos lidando com cultura material e, de certa forma, estamos lidando com gente, com processos humanos e processos sociais. Apesar desse laço temporal, de centenas de anos e de todos os desdobramentos teóricos e filosóficos que nós temos hoje, na maior parte das vezes continuamos engessando a cultura material.

Além disso, o gosto e o interesse pela Arqueologia são notórios. Seja pela mídia, seja pelo Indiana Jones, seja pelo que for, nós temos uma curiosidade enorme sobre o nosso passado. Até porque o passado é uma forma sublime de entendermos nossa própria condição humana atual. É uma busca quase vital que nos faz perguntar "de onde nós viemos?", "onde nós estamos" e "para onde pretendemos ir?". A arqueologia acaba, também, por uma mágica ou encantamento, sendo uma área muito procurada e muito interessante, e isso não encontra eco tão somente no senso comum, mas também em termos teóricos.

Para Michael Shanks e Christopher Tilley, o museu é o maior elo entre a Arqueologia (enquanto disciplina e profissão) e o grande público não arqueólogo. Colin Renfrew e Paul Bahn apontam que a Museologia é uma disciplina que interpreta e exibe o passado. Assim, ela não só exibe, mas também cria versões sobre o passado, já que quando representamos algo, não só (re)apresentamos, reinventamos. É uma linguagem, é uma nova visão, é uma nova possibilidade de observar e criar um sentido do passado, no presente. Além disso, Stephanie Moser vê o museu como veículo não acadêmico de representação pública da Arqueologia. Observa-se, portanto, que essa relação entre cultura material e museu, arqueologia e museu, não chega a ser nova nem a surpreender.

Todavia, ainda que haja esse interesse, a visão que nós construímos sobre o passado musealizado pode ser representada pelas duas frases a seguir. Uma de um famoso escritor, Paul Valéry, que em 1931, após uma visita ao Louvre, escreveu um breve texto muito elucidativo em uma crítica à modernidade, que diz o seguinte: "Não gosto tanto dos museus, muitos são admiráveis, nenhum é delicioso. As ideias de classificação, conservação e utilidade pública - que são justas e claras - guardam pouca relação com as delícias". A outra é um infame (no sentido de não ter fama) comentário feito no livro de sugestões do Museu de História Natural de San Diego, em que o camarada disse o seguinte: "Eu não sei o que a História Natural significa e, para mim, o museu significa 


\section{Revista de Arqueologia Pública}

morte, empalhamento e passado". Isso reforça a ideia de que, talvez, o nosso modelo de preservação e de ativação da cultura material esteja senão falido, ultrapassado.

Apesar de sua declaração, Paul Valéry não conheceu a Nova Museologia, não conheceu a Museologia Social, mas aparentemente sua frase permanece bastante viva, provocativa e deixa qualquer profissional de museu rubro de vergonha.

Por fim, Andreas Huyssen fala o seguinte: "Tanto para a Baudrillard quanto para Jeudy a musealização é precisamente o oposto de preservação: é o mesmo de que matar, congelar, esterilizar, desistoricizar, descontextualizar, esses são claramente os slogans da velha crítica que considerava o museu uma câmara mortuária".

Por motivos também diversos, eu venho trabalhando muito a associação entre museu e cemitério, os quais por mais que pareçam lugares que convidam à morte, são, em tese e filosoficamente falando, lugares que convocam à vida. Os museus, assim como os cemitérios, são criados pelos vivos e para os vivos. Eles são lugares para ancorar, de alguma sorte, a memória para que criemos algum laço identitário com o nosso passado e de forma que consigamos nos estruturarmos e vislumbrarmos o futuro. Os museus e os cemitérios também servem para isso. Por outro lado, isso não implica dizer que os museus devam sepultar a cultura material. A função do museu é justamente a de prover vida e sentido ao patrimônio e à cultura material.

Ontem, eu refleti sobre algumas crendices patrimoniais, algumas ideias que nós carregamos talvez desde o lluminismo e que ainda hoje se fazem, de alguma forma, presente $^{4}$. A primeira crendice é acreditar que acumular é preservar. Ela geralmente é acompanhada da frase: "O meu museu tem 150 mil itens!", que em geral é dita com muito orgulho. "O meu museu - portanto, propriedade minha - tem 150 mil itens!". Quando ouço isso, fico me perguntando: "Você não está preocupado com isso? Porque eu estou".

Por ser da Museologia da UFPel e também por participar de eventos da Conservação e Restauração, eu já não levo mais lenço quando os curadores de museus vão falar. Não levo mais. Porque o que ocorre é sempre o muro das lamentações sem fim. Nesses contextos, eu geralmente pergunto: "Vocês têm política de acervos dentro do museu de vocês? Pelo menos vocês refletem sobre isso?". Senão, eu não puxo o lenço, até porque eu não o levo mais.

\footnotetext{
${ }^{4} \mathrm{O}$ autor observa que as considerações aqui postas foram feitas na forma de um ensaio, de uma possibilidade e, portanto, estão abertas às críticas e às reflexões.
} 


\section{O PATRIMÔNIO COMO ATO JURÍDICO}

Esta também é outra questão. Bom, vem da Revolução Francesa, estende-se no Pós-Guerra, com a criação do ICOM (Conselho Internacional de Museus), e consiste na ideia de que o patrimônio é algo raro, único, magnânimo, maravilhoso, e que basta você ter um decreto que se pode pretensamente preservar esses restos da história. Então, por que isso aqui é patrimônio? Vamos explicar: “É patrimônio porque está na lei!". Esta é a afirmação que vem logo em seguida. É um patrimônio que eu chamo de patrimônio por decreto. É preciso dizer, no entanto, que não estou aqui para defender que se deva rasgar a palavra da lei. Pelo contrário, é uma estratégia fundamental para a salvaguarda do patrimônio nós termos uma legislação que embasa sua preservação. A minha questão é: a preservação começa e termina no decreto?

A outra questão é (todas são encadeadas) a ideia de imanência do valor patrimonial, que é o que eu chamo de patrimônio de nascença. Nasce patrimônio, nasce magnânimo é uma herança indiscutível. Isso geralmente vem acompanhado da frase: "Este patrimônio tem um sentido universal e incontestável para a história da humanidade", segundo a qual o patrimônio fala por si só.

"Basta você acessar o patrimônio para alcançar a luz" - esta também é uma ideia iluminista que persiste e que tem tudo a ver com a quarta crendice, que é "o objeto é portador de conhecimento". Conforme esta crendice, quanto mais nós acessamos esses restos, essas coisas, quanto mais acessamos a cultura, mais culto ficamos. Esta é a ideia de "basta ver para aprender". Desse modo, quando vou visitar Paris, tenho de ir ao Louvre e de lá sairei muito mais iluminado do que quando eu estava fora dele. 


\section{A IDEIA DE QUE ACUMULAR É PRESERVAR}

$\mathrm{Na}$ verdade, muitas vezes o acúmulo tem um sentido contrário à preservação. $\mathrm{O}$ acúmulo acrítico está muito mais ligado à própria rota de morte patrimonial do que à ideia de vida. Qual é, então, a cadeia operatória em que nos encontramos hoje? Isso não é uma crítica, isso é uma constatação ${ }^{5}$.

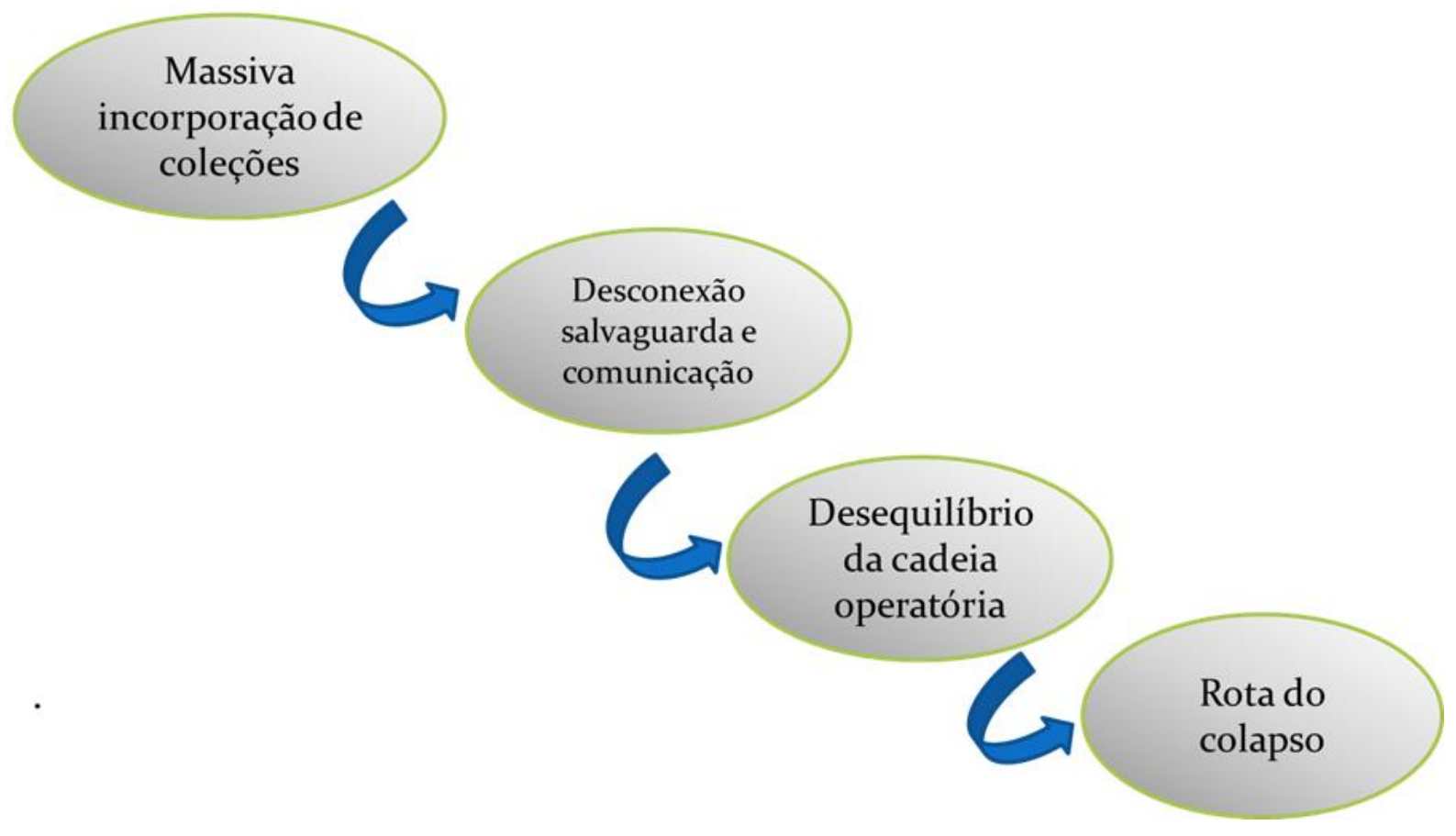

Nós temos de lidar com este modelo. Este modelo não é reversível, acredito eu, mas nós temos de pensar em um modelo que se desvie dessa rota que é a massiva incorporação de coleções, uma desconexão patente entre as políticas de salvaguarda e pesquisa e as políticas de extroversão, um desequilíbrio notável nessa cadeia operatória de musealização ou de patrimonialização (como vocês bem entenderem), que leva a uma rota de colapso que é o que nós vivemos hoje. Rota de colapso esta, aliás, que é acentuada por reservas técnicas saturadas. Nós estamos sempre pensando em aumentar a reserva técnica - e esta é uma preocupação real -, mas muitas vezes estamos pouco preocupados em pensar políticas de racionalização da entrada de coleções.

Se fossem bichos, os museus de Arqueologia seriam bichos impossíveis: um bicho que tem boca de hipopótamo e estômago de sabiá. Ele incorpora muito e processa pouco, por questões óbvias: porque nós não temos um corpo funcional adequado, não temos

\footnotetext{
${ }^{5} \mathrm{O}$ autor refere-se à arqueologia por contrato.
} 
infraestrutura. Então, se fosse um bicho, este não entrava na arca de Noé, meu amigo, porque ele não sobreviveria.

Paul Valéry - trago ele novamente - diz o seguinte: "Mas nossa herança é esmagadora. O homem moderno, extenuado pela enormidade de seus meios técnicos, se empobrece pelo excesso mesmo de suas riquezas. O mecanismo das doações e dos espólios - a continuidade da produção e das aquisições - e essa outra causa do crescimento que resulta das variações da moda e do gosto [...], e concorrem sem trégua para a acumulação de um capital excessivo e portanto inutilizável". É isso o que nós enfrentamos muitas vezes em nossas realidades museológicas - muito acervo e pouco patrimônio. Eu não digo patrimônio por decreto nem um patrimônio por nascença. Refiro-me a um patrimônio como categoria de pensamento ${ }^{6}$. Refiro-me ao patrimônio como apropriação dos referenciais patrimoniais. A apropriação simbólica do patrimônio arqueológico é que efetivamente garante a vida patrimonial daquilo que chegou ao fim de sua biografia.

Este é o resto que nós vemos inutilizado [o autor indica uma imagem de artefatos osteológicos dispostos no chão de um galpão, em caixas e em sacos plásticos, como se estivessem em um depósito ou lixeira $\left.{ }^{7}\right]$. O problema dos esqueletos não é estarem dentro do museu. Alguns dos radicais, contudo, dirão: "Tem problema sim! Quem são vocês, caras pálidas, para se apropriarem dos nossos antepassados e colocá-los em uma vitrine?". Alguns se incomodam, mas eu não vou exatamente por esse caminho. Acho que o sentido de dar vida ao que chegou literalmente à morte é trabalhar com o sentido efetivamente patrimonial, que não se esgota, por sua vez, na pesquisa técnica e científica. Em minha modesta opinião, todo o investimento técnico-científico e todo o investimento público realizados nesses museus somente fazem sentido se os acervos encontrarem eco do lado de fora desses espaços. Então, não é uma crítica à coleção, mas uma crítica à forma muitas vezes de como o patrimônio arqueológico é tratado por instituições que têm, em sua porta, uma placa com a afirmação "eu preservo o patrimônio", quando, na verdade, muitas vezes estamos matando duplamente o patrimônio - a primeira morte é física, e a segunda, semântica.

A minha questão é: todo esse aparato jurídico-burocrático garante a efetiva preservação? É isso que a garante? Ora, se garantisse, nós estaríamos a salvo. Não

\footnotetext{
${ }^{6}$ Referência ao autor Reginaldo Gonçalves, em "O espírito e a matéria: o patrimônio enquanto categoria de pensamento".

${ }^{7}$ Imagem não reproduzida por motivos éticos.
}

\begin{tabular}{|l|l|l|l|l|l|l}
\hline (C) Rev. Arqueologia Pública & Campinas, SP & v.11 & n.2 & p. 270 & Novembro/2017 & ISSN 2237-8294
\end{tabular}


haveria pichação em busto nem prédio público literalmente tombado no chão. Vemos, então, que esse é um modelo que também não está funcionando muito bem.

A meu ver, todo esse aparato jurídico-burocrático tem de ser endereçado sobretudo - repito exaustivamente - à apropriação pública do bem público, e isso não se dá por decreto, como eu defendo. Eu acredito que o patrimônio não é exatamente um espírito do estado, mas um estado de espírito. Não basta você falar que ele tem valor, é preciso que as pessoas enxerguem o seu valor. Isso significa criar formas de calibrar o olhar para que as pessoas enxerguem os fantasmas que habitavam o lugar.

Eu falo isso porque as minhas orientandas geralmente dizem: "Ai, Diego, ninguém dá valor aos vestidos que estão no Museu da Baronesa. Nós investimos 'zilhões' em conservação, costuramos aquilo, e ninguém dá valor. O que nós fazemos?". A minha resposta é enfática: "Façam o seguinte: peguem esses vestidos, convoquem as pessoas e façam um ritual muito bacana de queima. Vamos fazer isso?". Elas literalmente choraram. Choraram porque eram conservadoras. Mas eu fiz isso propositalmente. Depois, falei: "Talvez parem de mexer na matéria e invistam na alma, invistam no espírito. Eu fiz isso pela provocação, pela ameaça de perda". Duas semanas depois, elas me disseram: "Você sabe por onde esse vestido passou, meu querido?", me trazendo, inclusive, uma biografia enorme daqueles trecos (para mim, eram todos cacarecos, uns cacarecos bonitinhos). "Você sabe a história desses cacarecos?", perguntaram, "eles eram lá de Portugal, passaram por não sei o que, eram o costume de não sei quem". Aí, eu falei: "Bom, agora não queimem, não, porque agora isso fez sentido".

Elas se deram conta, então, de como o sentido não é pulsante no objeto. Ele não vem de dentro para fora; o sentido é, necessariamente, uma atribuição. A biografia dessas coisas e a biografia das pessoas nas coisas colaboram para você ativar o valor patrimonial desses cacarecos. Pensando nisso, cito uma frase, da qual gosto, de José Reginaldo Gonçalves: "Um patrimônio não depende apenas da vontade e decisão política de uma agência de Estado. Nem depende exclusivamente de uma atividade consciente deliberada de indivíduos ou grupos. Os objetos que compõem o patrimônio precisam encontrar 'ressonância' junto a seu público" (2005)

Certa vez, eu vim numa atividade aqui no Museu do Sambaqui de Joinville - que nós estávamos conversando sobre o prédio e tudo o mais - , e em determinado momento alguém falou o seguinte: "Ah, este museu tem um gasto muito grande. Ninguém sabe quanto custa o museu". Eu respondi: "Nossa, mas que iconoclasta um depoimento como esse...". Isso acabou tendo uma reverberação muito grande: "Não, o museu não vai fechar, 
não, ora bolas! Que história é essa? Esse museu tem muita importância". Ou seja, é a ressonância que garante o patrimônio. O Museu da Baronesa - no qual estão os vestidoscacarecos - ficou fechado mais de um ano e ninguém abriu o bico. Ora, será que não está faltando ressonância? Talvez seja isso que garanta a sobrevivência do bem patrimonial; salvo isso, fecha-se.

\section{A IMANÊNCIA DO PATRIMÔNIO}

É a ideia do patrimônio por nascença. Eu gosto desta frase da Marilena Chauí, que trabalha com a ideia de semióforo $^{8}$, a qual eu acho que tem tudo a ver com a ideia de patrimônio: "Pessoas, lugares, objetos, animais, meteoros, constelações, acontecimentos, instituições, estandartes [...]". Enfim, tudo pode ser semióforo. E o que é semióforo? "É alguma coisa ou algum acontecimento cujo valor não é medido por sua materialidade e sim por sua força simbólica". Força simbólica esta que é mediadora entre o sagrado e o profano, o presente e o passado e os vivos e os mortos. É isso o que eu chamo de os fantasmas que habitam o lugar.

Se as pessoas conseguissem enxergar os fantasmas que habitavam os vestidos dos quais eu estava falando anteriormente, talvez conseguissem dar um pouco mais de valor àqueles cacarecos. Eu acredito firmemente, por trabalhar sobretudo com comunicação, que o valor não é imanente; ele é ativado. No campo dos museus, o valor é ativado pela performance museal $^{9}$; é ativado pela comunicação; é ativado pelo encantamento; é ativado pelo tesão. Palavras estas que estão muito desconexas com a própria ideia de ciência. Parece que todo esse afã de inventariar e organizar o mundo congelou o nosso coração e nos fez esquecer de que somos, em realidade, agentes sociais.

Waldisa Russio dizia isso em 1984: "Nós temos de nos dar conta do papel social que temos". Para isso, nós não temos de pensar a extroversão como o final de um processo, mas pensá-la antes do próprio processo se iniciar. Esta é uma questão central: nós não conseguimos criar patrimônios e musealizar sítios se fazemos isso de dentro de escritórios, com as nossas visões, nossas concepções e apoiados somente nessa pretensa ciência que tudo sabe e tudo responde. [O autor passa a ler uma citação de Reginaldo Gonçalves] "É preciso também não esquecer que, enquanto portadoras de uma 'alma', de um 'espírito', as

\footnotetext{
${ }^{8}$ Esta ideia de semióforo é disseminada principalmente por Krzysztof Pomian, que trabalha a questão do colecionismo.

${ }^{9} \mathrm{O}$ autor refere-se aqui ao conceito sistematizado pelo museólogo Bruno Brulon.
}

\begin{tabular}{|l|l|l|l|l|l|l}
\hline (C) Rev. Arqueologia Pública & Campinas, SP & v.11 & n.2 & p. 272 & Novembro/2017 & ISSN 2237-8294
\end{tabular}




\section{Revista de Arqueologia Pública}

coisas não existem isoladamente, como se fossem entidades autônomas; elas existem efetivamente como parte de uma vasta e complexa rede de relações sociais e cósmicas, nas quais desempenham funções mediadoras fundamentais entre a natureza e cultura, deuses e seres humanos, mortos e vivos, passado e presente, cosmos e sociedade, corpo e alma etc.".

Outro ponto de vista bem prático é imaginar que aquela máscara mortuária que eu mostrei no Peabody Museum, sozinha dentro de uma vitrine como mostruário, basta para as pessoas entenderem quem a usava, como a usava, por que a usava e por que foi descartada. A não ser que seja um público-chico-xavier, os fantasmas não vêm automaticamente, eles são fruto de ativação.

\section{A CADEIRA DO BARBEIRO}

Esta colocação não é um exemplo de arqueologia, mas um exemplo do Museu Grupelli (UFPel, Pelotas - RS), que é um dos museus em que atuo por intermédio de um projeto de extensão que coordeno.

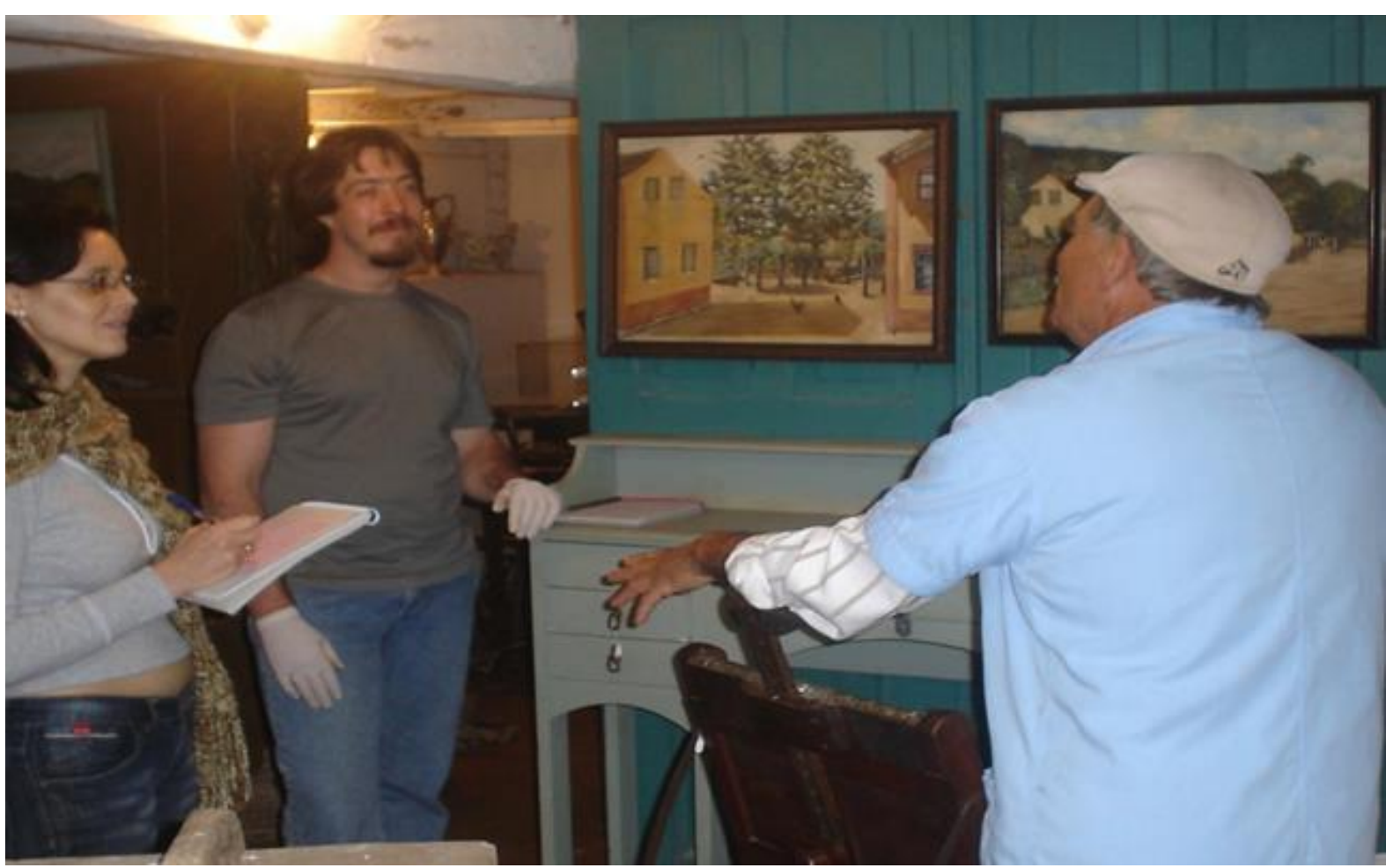

Fonte: acervo do Museu Gruppelli. 


\section{Revista de Arqueologia Pública}

Quando a cadeira chegou lá, o museu já existia há dez anos. Esta chegada foi fruto de uma mobilização da própria comunidade, de uma professora, de um fotógrafo e da própria família. A Universidade não estava exatamente na jogada. Quando nós chegamos lá, no $10^{\circ}$ aniversário do museu, havia um monte de cacareco, um monte de coisas, e a nossa função era a de dar sentido a essas coisas. Entretanto, nós não conseguimos dar sentido com as portas fechadas, somente conseguimos com as portas escancaradas, no sentido de ouvir as narrativas - é a única forma de conseguir conhecer o espírito das coisas, nesse contexto. Nisso, entrou um senhor:

— O senhor já visitou o museu?

$-\operatorname{Sim}$.

— Muitas vezes?

- Uhum.

— E dessas coisas, de tudo isto que está aqui, pelo que o senhor tem algum apreço?

— Ah, meu filho, por esta cadeira de barbeiro.

Foi então, meu amigo, que, na narrativa dele, veio uma rede emaranhada de atores humanos e não humanos (inspiração latouriana ${ }^{10}$ ), mortos vieram à vida e o passado voltou ao presente. Foi uma profusão de personagens que apareceram por meio dessa "cadeirachico-xavier" e que dão um efetivo sentido a esse cacareco.

Anos mais tarde, um senhor entrou no Museu, começou a identificar umas pessoas em uma foto e disse: "Este daqui é Fulano Ferrari". Eu, ao escutar, disse: "Opa!". Então, Seu João Petit - o senhor presente nas fotografias acima e abaixo - contou que a cadeira pertencia a alguém da família Ferrari antes de ser herdada por ele. Em seguida, fomos conversar:

— Ah, é o filho bêbado dele...

— Qual é o paradeiro do filho bêbado?

— Morreu. Mas a filha está viva, mora ali.

Bom, não vou me alongar, mas vêm outras camadas de narrativas, mais pretéritas do que a do Seu João Petit. Olhem aí [o autor indica o slide].

\footnotetext{
${ }^{10}$ Antropólogo e filósofo Bruno Latour.
}

\begin{tabular}{|l|l|l|l|l|l|l|}
\hline (C) Rev. Arqueologia Pública & Campinas, SP & v.11 & n.2 & p. 274 & Novembro/2017 & ISSN 2237-8294
\end{tabular}




\section{Revista de Arqueologia Pública}

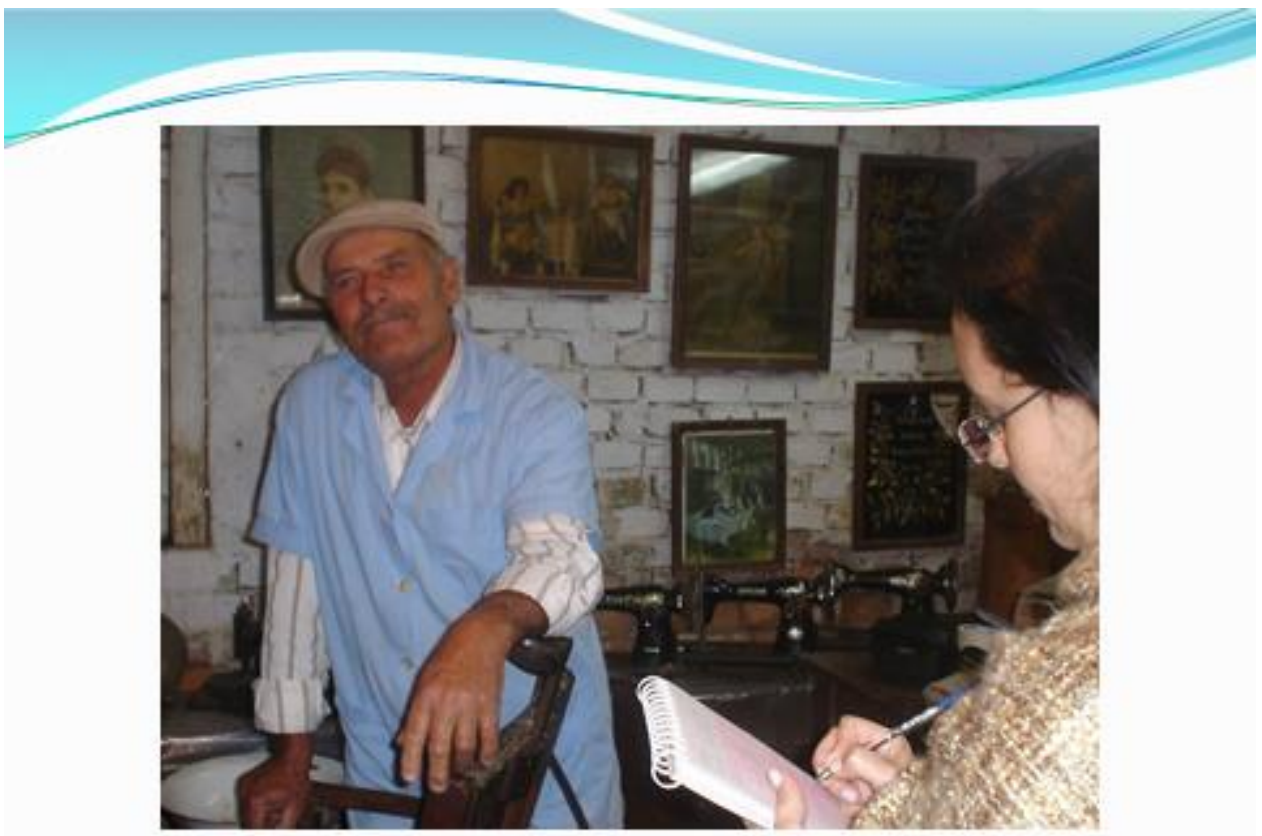

Fonte: acervo do Museu Gruppelli.

Tem como não dizer que esta cadeira age diretamente nesse cidadão a ponto de se tornar uma extend of self (a extensão de si)? Dê um chute na cadeira para ver se este senhor não gritará "aí". Ele gritará.

Então, o que nós temos de fazer? Qual a nossa função como museólogos que trabalham com essas realidades? A resposta é: fazer com que as pessoas enxerguem os fantasmas que habitavam o lugar. É justamente isso. É fácil? Não. Tem receita? Claro que não. Mas é isso que devemos ter em mente quando acordamos todos os dias e nos perguntamos: como podemos dar sentido a esses trecos que sobreviveram ao passado e hoje estão de forma espectral aporrinhando a nossa vida? 


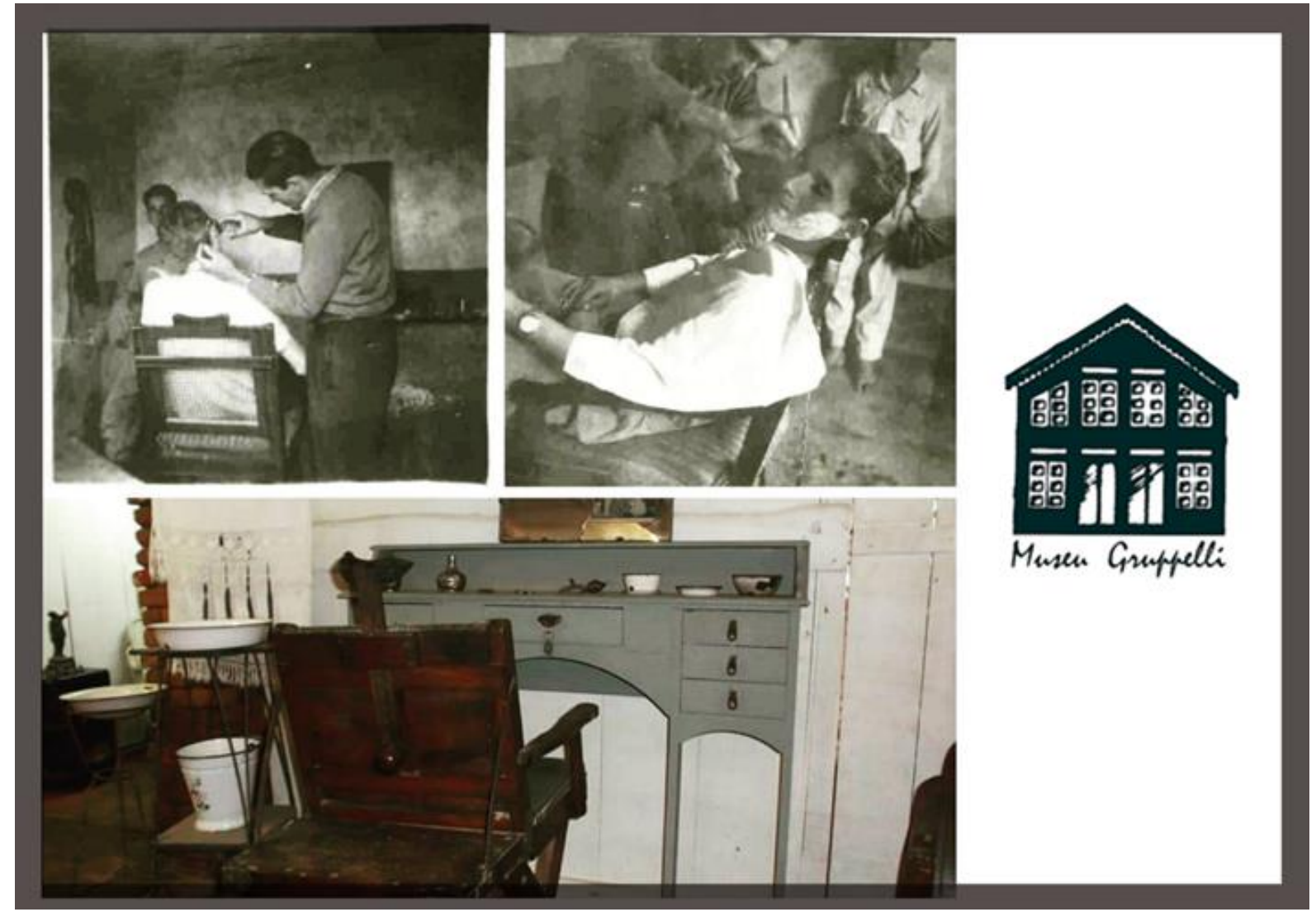

Fonte: acervo do Museu Gruppelli.

Esse é, então, o primeiro ponto. Eu não critico o modelo de museu tradicionalcolecionista. Acho esse modelo fundamental. Não o colocaria na mesma esparrela da Revolução Francesa de "vamos queimar tudo?! Vamos fechar os museus?!". Não, não, não. Deixem os museus existirem, deixem esse modelo de museu existir. Mas podemos criar novas linguagens, inclusive dentro desses próprios museus. Como acreditar na ideia de que as pessoas desfilando por essas vitrines e olhando essas coisas entenderão as relações sociais que subjazem os trecos? Elas não compreenderão! "Ah, então colocarei um texto erudito." Elas continuarão não compreendendo. A grande questão, portanto, é: vamos demolir os museus? Não. Vamos dar novas linguagens (potencialidades discursivas) para essas mesmas coisas.

Eu tenho de fazer uma propaganda aqui, e não é porque a minha tese foi com base no Museu Sambaqui de Joinville. Se vocês estudarem a história deste museu, verão que "os caras" são extraordinariamente criativos e fantásticos para lidar com patrimônio. É uma 
inspiração! "Ah, mas eles têm dinheiro." Não têm dinheiro! O past food"11 (ação educativa proposta pelo Museu), que vocês acabaram de ver em uma das apresentações anteriores, é uma forma brilhante de lidar com cultura material sem as materialidades em si. As materialidades que eu digo são os artefatos da cultura material que nós herdamos do passado e que merecem muita atenção. Mas, no exemplo em questão, nós estamos lidando com outra sorte de materialidade, de apropriação do patrimônio, de valorização, pela melhor forma possível — pelo estômago. Não é isso?

Então, em 1970, ninguém lia $A$ Nova Museologia ainda, e o de Varine ${ }^{12}$ era um jovem sonhador. Nesse período, "os caras" do Museu estavam indo a campo, indo tratar da preservação do patrimônio arqueológico in situ. Um modelo extremamente inovador para as décadas de 1970 e 1980.

Qual é, entretanto, o papel do Museu nessa seara? É fornecer uma segunda chance de vida à cultura material. É transformar coisas, trecos e troços em patrimônio, e não somente o patrimônio como ato jurídico, mas sobretudo o patrimônio como categoria de pensamento, patrimônio como ressonância, patrimônio como apropriação ${ }^{13}$. Para isso, nós temos os processos técnico-científicos da própria área que dialogamos com outras áreas, dependendo da tipologia de museu, e temos essa ideia da performance museal, que é a de justamente seduzir as pessoas, e isso não pode ser esquecido em nosso horizonte curatorial, por mais dura que seja a nossa realidade.

\section{PATRIMONIALIZAÇÃO}

Neste tópico, só trarei alguns exemplos. Atentem-se para a seguinte ideia de Susan Pearce: "Os objetos encontram-se relacionados localmente a outros artefatos e ao contexto, e o estudo dessas relações pode ser muito produtivo para a compreensão do papel do artefato. Inevitavelmente, não se terá o registro da maioria dos detalhes sobre materiais em coleções antigas e, assim, a compreensão que daí poderia resultar está irremediavelmente perdida; por outro lado, as oportunidades são interessantes para materiais que estão sendo incorporados".

\footnotetext{
${ }^{11} \mathrm{O}$ past food redunda em fazer os alimentos que os sambaquieiros faziam, em uma parceria do Museu com o Curso de Gastronomia da Univille, com base nas pesquisas realizadas na região.

12 Hugues de Varine-Bohan.

${ }^{13} \mathrm{O}$ autor novamente recorre ao antropólogo Reginaldo Gonçalves.
}

\begin{tabular}{|l|l|l|l|l|l|l}
\hline (C) Rev. Arqueologia Pública & Campinas, SP & v.11 & n.2 & p. 277 & Novembro/2017 & ISSN 2237-8294
\end{tabular}


Assim sendo, como pensar nas potencialidades que os nossos museus, ou lugares onde trabalhamos, têm? Às vezes, nós perdemos a oportunidade por não conseguir visualizá-las. O caso do sítio Santa Bárbara - no qual até a Ana Paula Leal ${ }^{14}$ também participou - é um trabalho, uma escavação, em que nós levamos as três áreas para o sítio: a Arqueologia, a Conservação/Restauração e a Museologia ${ }^{15}$. Todos tentando observar o que é patrimonializável desse processo, e nos damos conta de que o que é patrimonializável não é só cultura material — aquilo que é móvel —, mas também são os processos de patrimonialização; os próprios processos são musealizados.

Qual era, então, o nosso objetivo? Era observar e registrar a própria memória da pesquisa em campo, lançando questões para o campo, não como arqueólogos, mas como museólogos; tentar documentar esse novo ciclo de vida artefatual, do uso pretérito - que ficou congelado nas camadas estratigráficas - aos novos usos que estão sendo dados pela pesquisa científica atualmente; gerar uma forma de digerir essas informações de modo integrado, não só pelo ponto de vista da Arqueologia, mas também dessas áreas que estão em diálogo; e, adiante, propor um processo comunicativo contextual que não ofereça um produto final a ser consumido - um objeto numa vitrine - , mas tentar oferecer um processo de construção do patrimônio arqueológico. É abrir a caixa de Pandora para investigar quem são esses atores que estão investindo, hoje, no sítio. Até porque a Arqueologia, como disseram lan Hodder e Scott Hutson, na publicação "Reading the past", é duplamente contextual: o contexto dos artefatos e o contexto da Arqueologia produzida atualmente.

Qual é o sentido? É calibrar o olhar museal para a pesquisa arqueológica, tentando observar o que é exatamente passível de preservação. Nesse cenário, é muito comum que os museólogos se vistam de arqueólogos, mas eu lhes digo: "Não, não, aqui você é museólogo". Vamos tentar interpretar o porquê dessas pessoas estarem cavando aqui e não lá, por que eles estão levando isso no saquinho e jogando aquilo fora - entender o processo.

\footnotetext{
${ }^{14}$ Museóloga, arqueóloga e conservadora, atualmente pertencente aos quadros do CNA-IPHAN.

${ }^{15}$ Projeto de pesquisa coordenado pelo Arqueólogo Lúcio Meneses, intitulado Arqueologia da Escravidão.
} 


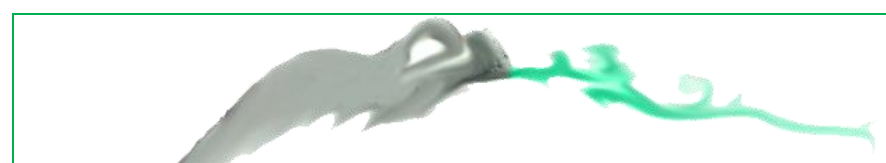

Revista de Arqueologia Pública

A seguir, temos somente exemplos de fotografia.
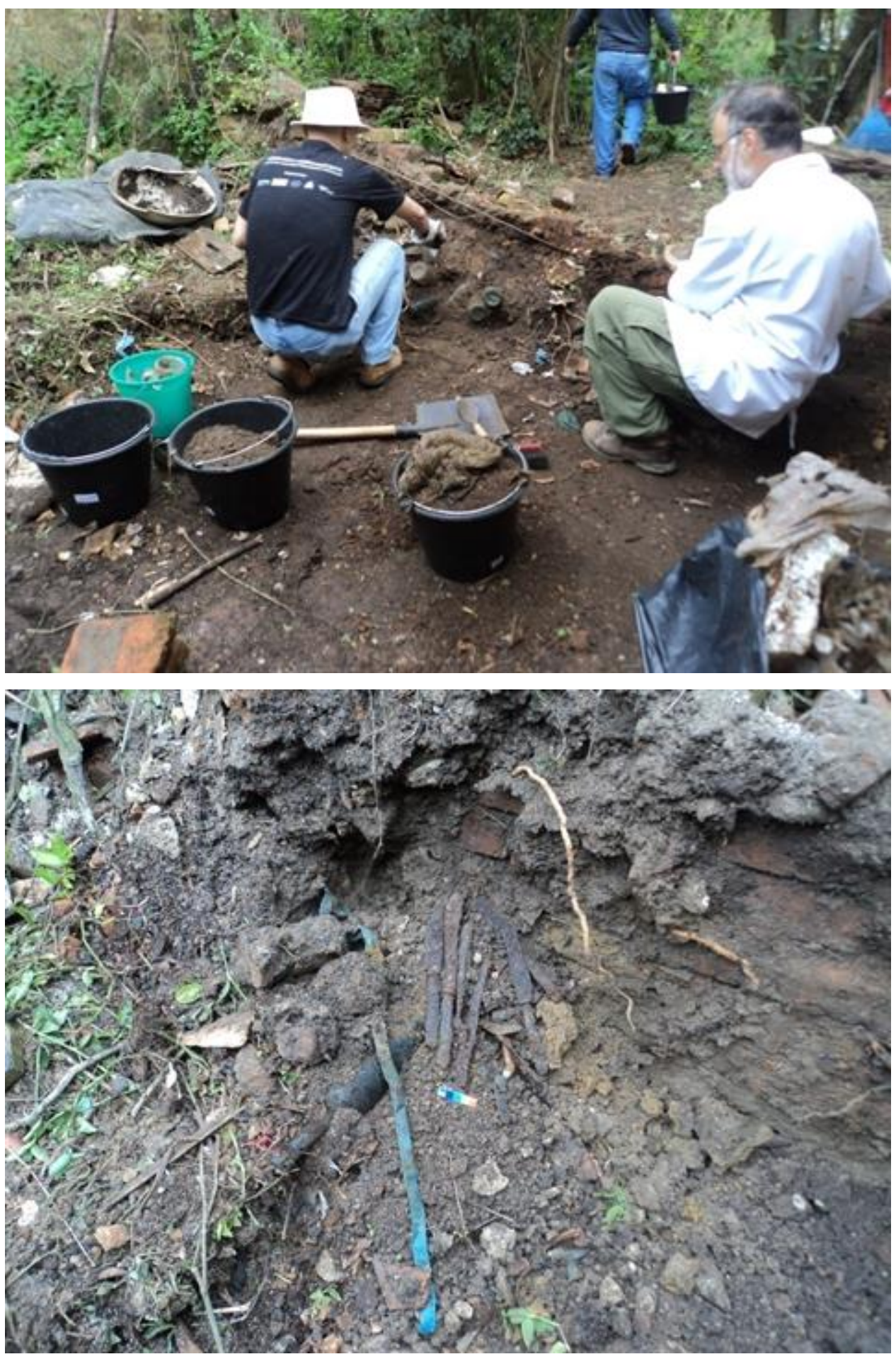


\section{Revista de Arqueologia Pública}

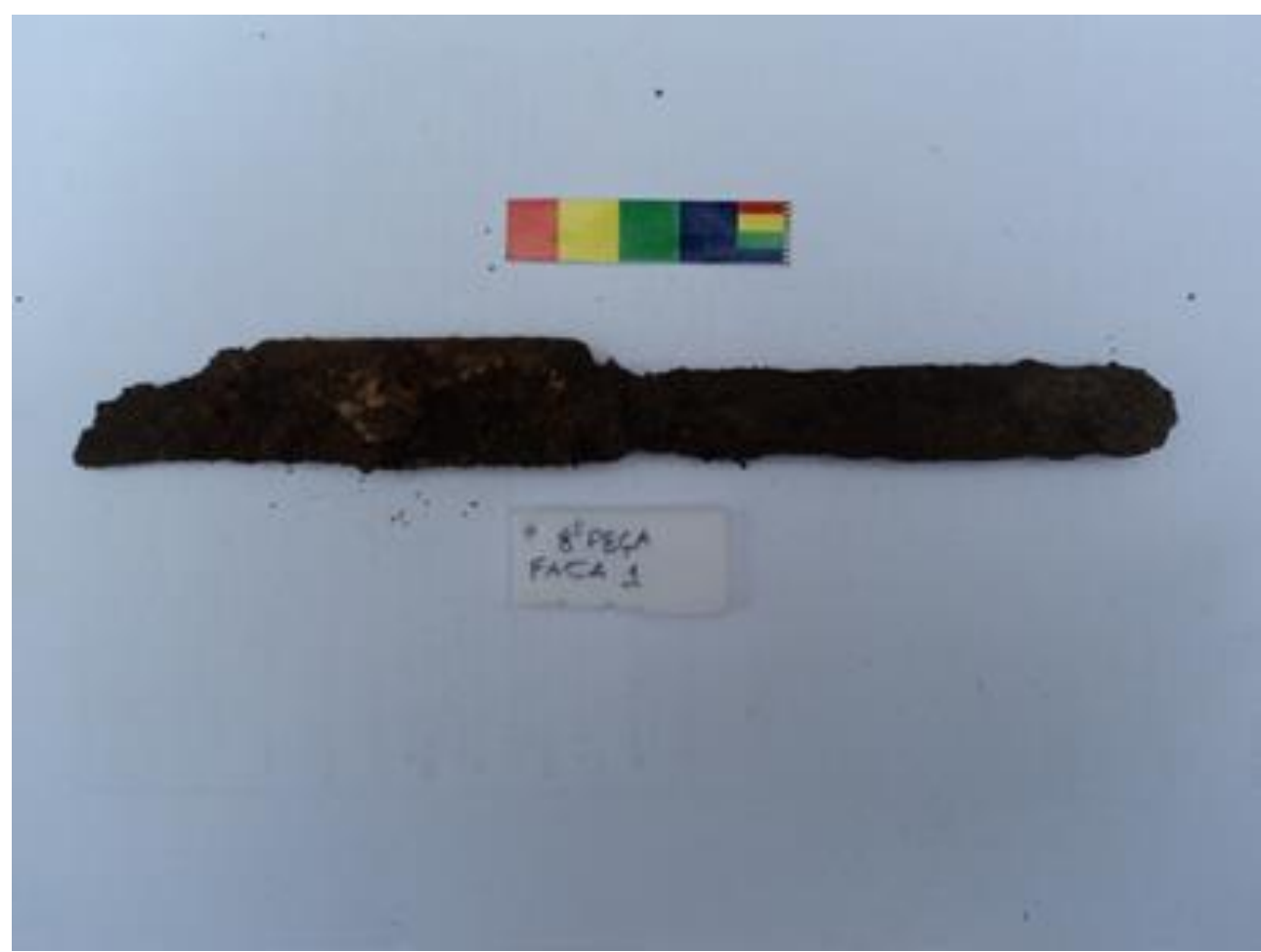

Fonte: acervo fotográfico do Laboratório Multidisciplinar de Investigação Arqueológica (LAMINA).

Respectivamente, temos uma imagem dos arqueólogos no sítio, uma imagem dos artefatos sendo revelados e uma fotografia de um dos artefatos, que estão na imagem, já em laboratório. Isso é mais para vocês terem uma ideia metodológica e não exatamente prática.

Uma frase que muito se relaciona com o que nós estávamos trabalhando aqui, hoje de manhã, isto é, com a interface entre essas áreas, é fundamental para nós alargarmos a ideia de preservação da cultura material. Enquanto nós estivermos trancados nos nossos departamentos, nas nossas searas, não conseguiremos ter um panorama amplo. Olhem que notável o que Cristina Bruno e Caldarelli - na época, eu ainda era um bebê escreveram: "Ao nosso entender, é absolutamente imprescindível que o museólogo participe da pesquisa, tanto em campo como em laboratório, para compreender sua finalidade e o processo científico pelo qual os dados são obtidos, registrados e analisados. Da mesma forma, o pesquisador deverá participar da concepção, elaboração e montagem da exposição, de modo a aprender a extensão e os limites desse meio de comunicação. $\mathrm{E}$ ambos devem trabalhar sobre o resultado obtido junto ao público" ${ }^{\text {16 }}$. Ou seja, a interdisciplinaridade é um excelente caminho para nós revertermos esse modelo.

${ }^{16}$ (CALDARELLI; BRUNO, 1982, p. 144). 


\section{VERSÕES DO PASSADO}

Bom, aqui é bem simples. A outra ideia que nós carregamos: a ideia de que a ciência responde tudo, de que a nossa leitura é a única possível.

Agora, quero mencionar a Janela Caleidoscópica, a qual eu achei uma proposta brilhante do Museu do Sambaqui de Joinville. O que é a Janela Caleidoscópica? (Olhem que frugal e, ao mesmo tempo, que interessante.) É uma janelinha que há neste museu, uma vitrinezinha que não continha nada. A equipe do museu se deu conta de em sua Reserva Técnica havia uma grande quantidade de objetos, de material arqueológico, que nunca foi visto por ninguém devido a essa pena capital da ciência que redunda em "nós não sabemos o que é".

Qual é o problema de o museu não saber o que é? Querem ver uma coisa? Qual foi a última exposição museológica que vocês visitaram em que havia uma interrogação gigante? O ponto é que a ciência não pode ter dúvida, e os museus têm medo de ter dúvida. Por isso, muitas vezes dizem: "Nós temos muitos materiais, mas não sabemos o que são, então, temos medo de expor".

Então, a equipe do museu dispõe o material lá ${ }^{17}$, reveza, coloca um artefato, e deixa que as pessoas criem as suas conjecturas contemporâneas sobre o passado. É uma imagem criada por elas e, sendo assim, o problema é delas. Que ótimo que elas criem. Há mais potência patrimonial na criação e na inventividade do que em uma caixa hermeticamente fechada.

Esta é outra questão [o autor exibe uma imagem de uma vitrine em um museu, com uma tela de vídeo acima de um artefato e, ao lado, dois arqueólogos narrando sobre os possíveis usos do artefato]:

\footnotetext{
${ }^{17} \mathrm{O}$ autor refere-se à vitrine destinada à atividade chamada Janela Caleidoscópica.
} 


\section{Revista de Arqueologia Pública}

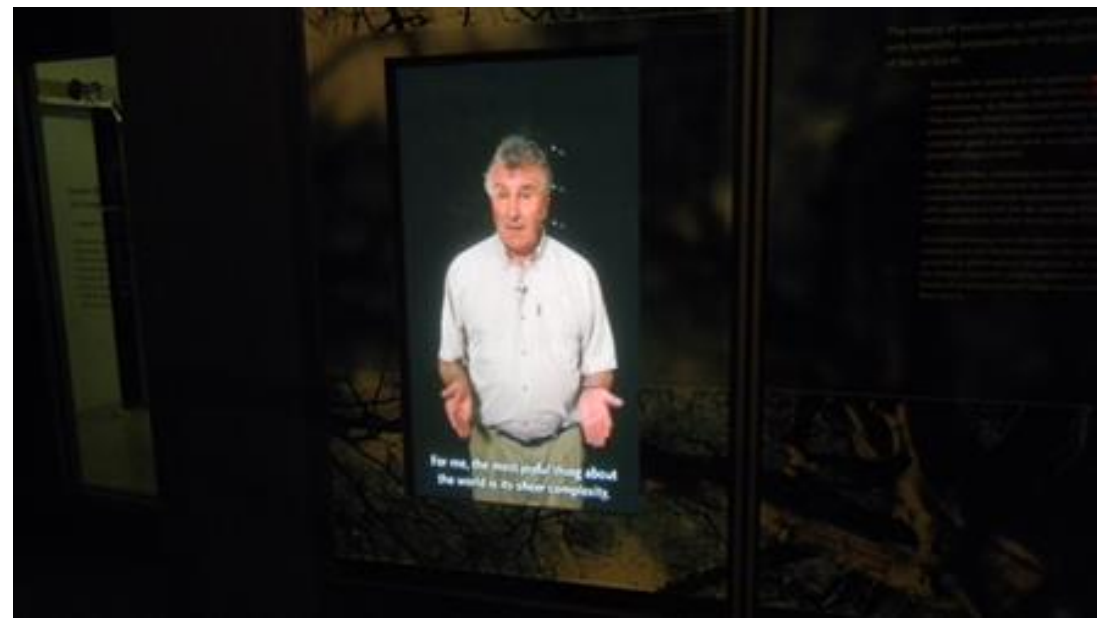

Fonte: o autor.

A fotografia acima foi tirada em um museu que visitei. Nele, há um artefato sobre o qual a equipe do museu também tem dúvida. Então, aparece um arqueólogo, na tela, explicando tudo em que ele acredita que aquele artefato é. Logo depois, aparece outro arqueólogo, que declara: "Discordo do colega". Nesse momento, você, espectador, fica com a interrogação. Que ótimo! Leve essa pulga atrás da orelha para casa, meu amigo!

Este [o autor aponta para uma imagem] é um quadro que está no Museu de Arqueologia de Xingó.

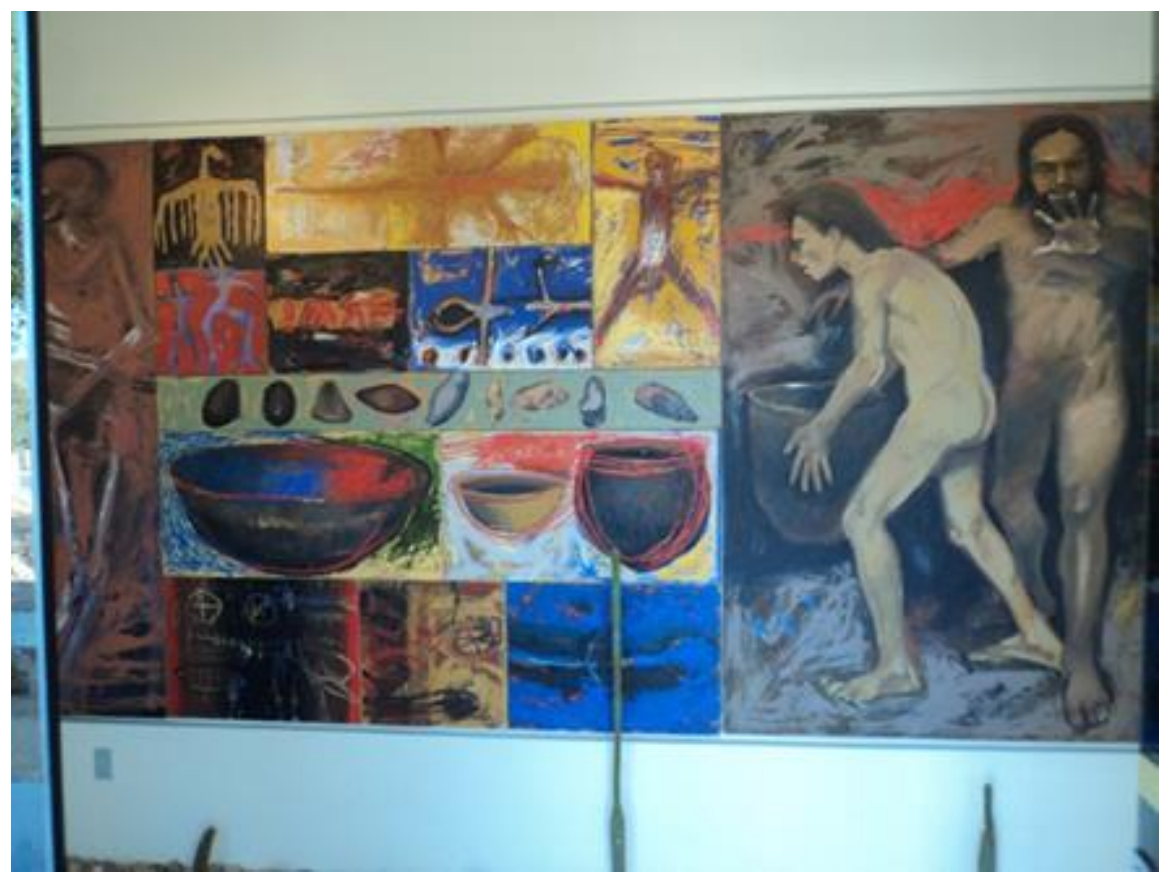

Fonte: o autor. 


\section{TRANSCRIÇÃO}

Revista de Arqueologia Pública

Ele é uma releitura atual e artística, dos artistas locais, sobre o passado. É outra linguagem, é mais uma leitura da cultura material.

\section{NOVOS USOS DA CULTURA MATERIAL}

Isto aqui é bacana [o autor indica imagens no slide]:

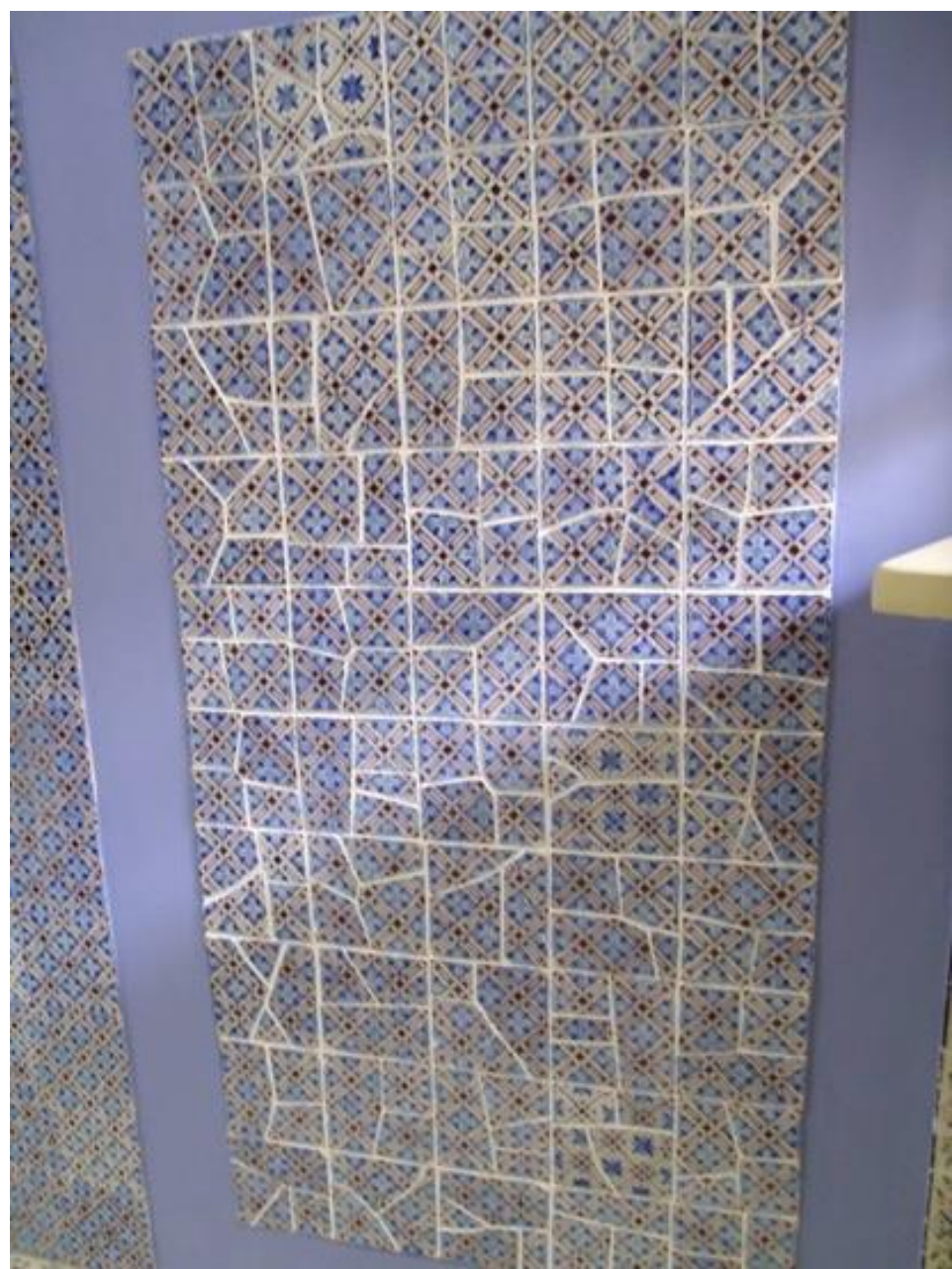




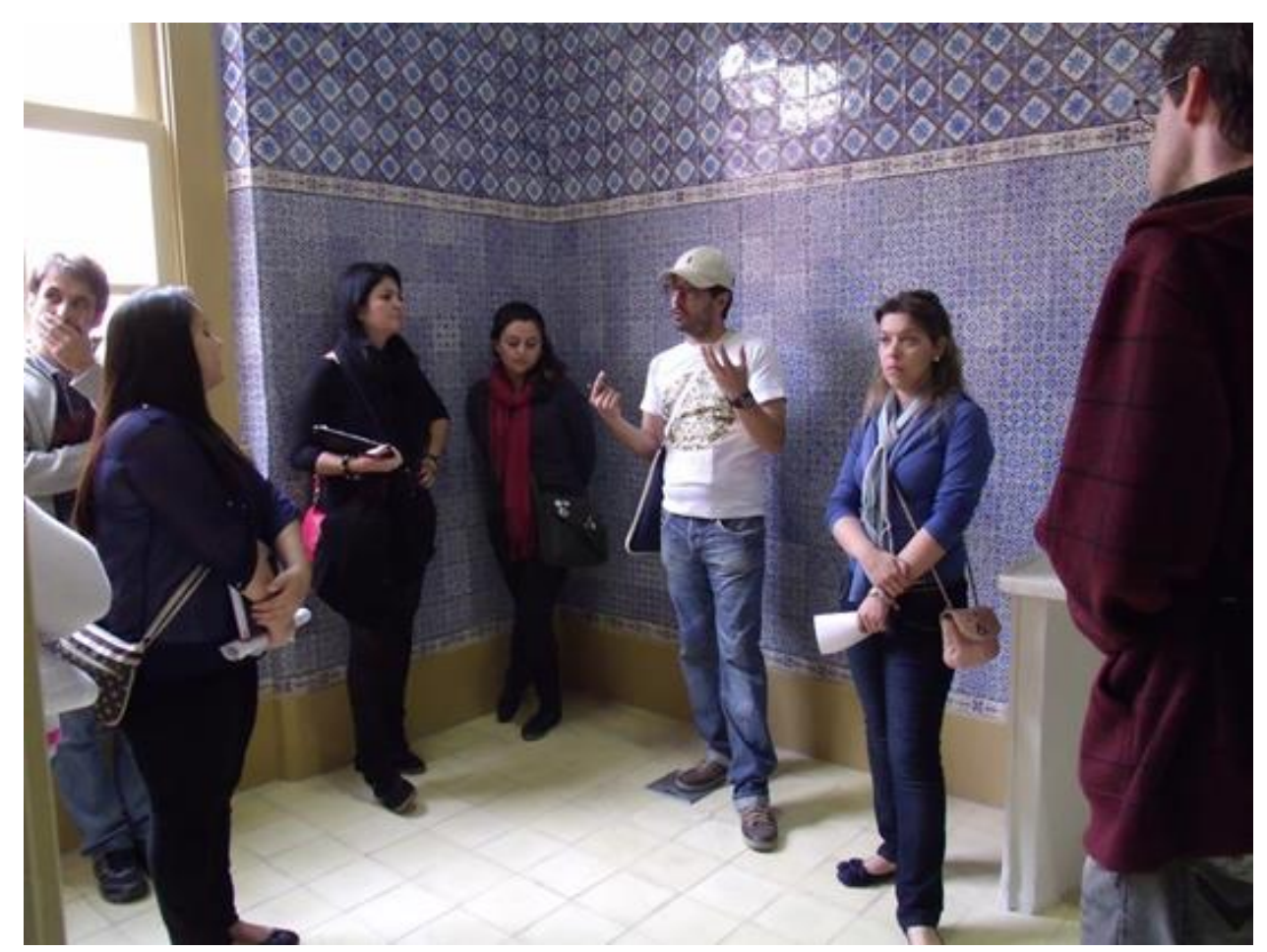

Fonte: acervo fotográfico do Museu do Doce, da Universidade Federal de Pelotas (UFPel).

Estão vendo estes azulejos? Eles foram fruto de uma pesquisa históricoarqueológica na Casa 8, em Pelotas, em que foram achados esses restos da construção da casa, que ficavam na cozinha. A equipe desse museu, o Museu do Doce, estava realizando uma reforma e montando a exposição e se deu conta de que tinha esse material arqueológico que estava dentro de caixas no LEPAARQ ${ }^{18}$. Ora, por que não? É preciso, inclusive, combinarmos uma coisa. Não podemos, de forma nenhuma, dizer que isso é descarte. Isso é mobilização de acervo. Retomando... O que aconteceu? O IPHAN (Instituto do Patrimônio Histórico e Artístico Nacional) foi consultado, deram baixa nesse material arqueológico e fizeram criterioso trabalho de amostragem ${ }^{19}$. Resultado: com essa mobilização do acervo, foram geradas muitas mais pesquisas do que com o acervo dentro da caixa. Como resultado dessa mobilização, parte desses artefatos foi para a cozinha da casa, que hoje é Museu, e hoje eles podem ser vistos, lidos, reinterpretados e revalorizados. Ou seja, a mobilização do acervo gerou mais potência patrimonial do que a morte simbólica dentro de uma caixa.

\footnotetext{
${ }^{18}$ Laboratório de Ensino e Pesquisa em Antropologia e Arqueologia da UFPel.

${ }^{19}$ A outra parte do material ainda está lá no Laboratório.
}

\begin{tabular}{|l|l|l|l|l|l|l|}
\hline (C) Rev. Arqueologia Pública & Campinas, SP & v.11 & n.2 & p. 284 & Novembro/2017 & ISSN 2237-8294
\end{tabular}




\section{Revista de Arqueologia Pública}

Que tal pensarmos em formas de mobilização do patrimônio arqueológico? Porque se nós falamos "descarte", que está no Código de Ética para Museus, vira um frenesi e ninguém fala nada. Não fala nada, isso é proibido. Por outro lado, se nós falarmos de mobilização, talvez tenhamos boas ideias.

Aqui, o último exemplo. Este é o Museu de Arqueologia de Itaipu [o autor indica o slide]. É o único museu de arqueologia vinculado ao IBRAM (Instituto Brasileiro de Museus) e está numa antiga ruína, no recolhimento de mulheres do século XVII. Nesse local, que lhe serve de abrigo, há artefatos arqueológicos em exposição, onde tem aquela capelinha e tudo o mais. Os dados, registrados pelo Arquivo Central do IPHAN - RJ, referem-se ao recolhimento abandonado como se fosse um longo período de destruição do bem patrimonial, até ele ser patrimonializado na década de 1950.

Quando chego nesse museu para realizar minha pesquisa de mestrado, na primeira investida em campo, um cara trôpego vem em minha direção e diz:

— Eu já morei aí dentro.

- Já morou?

- Morei. Depois que virou museu, nunca mais voltei.

É importante dizer que esse museu se situa em uma zona (Z13) em que há pescadores artesanais e está inserido em uma comunidade de pescadores na beira da praia, enfim, há toda uma particularidade.

Comecei, então, a conversar com esses pescadores e percebi que para a capelinha, que aparece como uma interrogação, na documentação do IPHAN (não se sabe o que é, se é recente ou não), há série de histórias e memórias.

Uma senhorinha de 90 anos disse: "Olha, eu lembro, meu filho, que quando eu era pequenininha, tinha festa aqui, vinha o circo, e essa capelinha servia de prisão para as pessoas que assaltavam o povo. Tinha um delegado aqui que prendia o pessoal na capela". Em seguida, outro pescador comenta: "Ah, mas aqui também era onde a gente assistia à aula. Os mais velhos davam aula para nós dentro da capela".

Vemos, então, uma enorme gama de fantasmas que abrigavam esse lugar. E o que aconteceu? Quando a capela foi patrimonializada, apareceu a famosa frase: "Isso agora é patrimônio. Ponha-se para fora". Em todo processo de patrimonialização, esses pescadores, seus discursos, suas ideias, suas concepções ficaram totalmente alijadas. Isso cria um grande divisor que muitas vezes é irreversível. 


\section{Revista de Arqueologia Pública}

Então, quando nós falamos, dentro do IPHAN - e isso não é uma crítica, é uma questão a ser colocada -, sobre propostas de patrimonialização, muitas vezes elas não passam de meras burocracias, enquanto a real preservação está justamente em conhecer as formas, as apropriações e como as pessoas enxergam o passado, hoje. Olhem lá [aponta para o slide]:

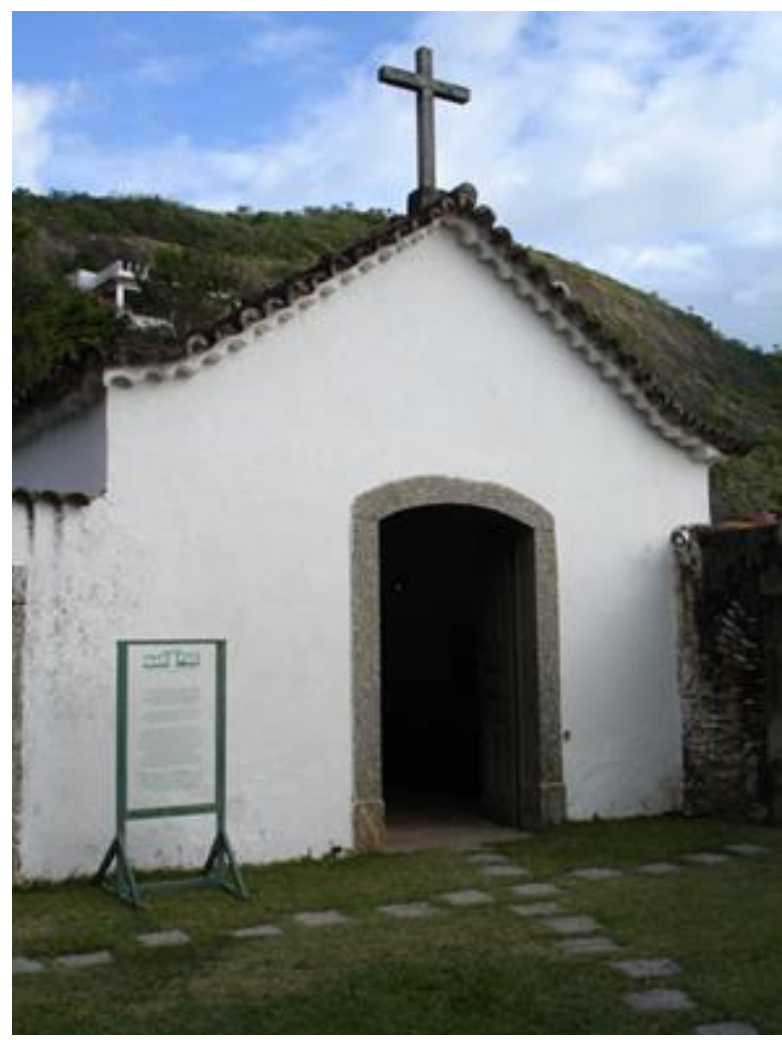

Fonte: o autor. 


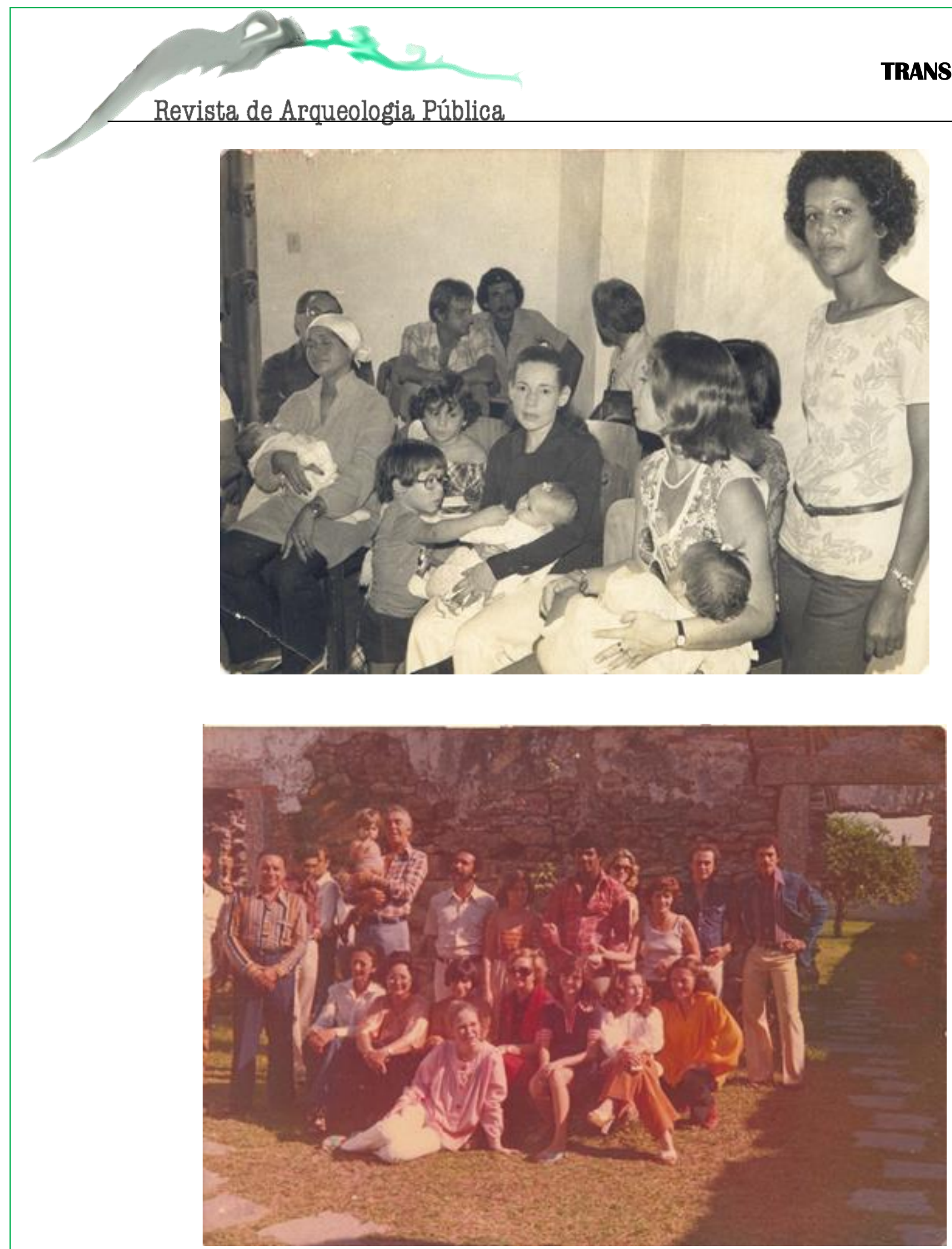

Fonte: fotografias cedidas por uma filha de pescador durante a pesquisa de mestrado do autor.

A foto na qual vemos bebês é um registro da última missa realizada na capelinha, porque depois eles (o IPHAN) fizeram de conta que ela não era uma capela consagrada e nunca mais pôde ter qualquer evento religioso lá dentro.

Esta é a última foto, e este [aponta para o slide] é o seu Chico. Julguem como vocês quiserem. Antes do IPHAN chegar lá, eles se apropriavam, sim, do sítio arqueológico. 
Brincavam e moravam no local, tinham leituras, sim, e, digo mais - não contem para ninguém. É segredo, tudo bem? Sei porque investiguei e fui fundo nisso - , uma parte expressiva do acervo desse museu é fruto de um arqueólogo amador chamado seu Hildo de Mello.

Seu Hildo, na verdade, era um grande interventor. O pessoal coletava o material arqueológico e entregava-Ihe. Ele depositou o material no museu como se pertencesse a si próprio, mas, na verdade, é fruto de coleta de todos da região, inclusive dela [aponta novamente para o slide]. Este material ficou escondido em uma reserva técnica e nunca foi visto por ninguém. O material que se exibia na exposição era de Lina Kneip, da arqueóloga do Museu Nacional. Por que esse material nunca foi visto? Porque era "endemoniado", fruto de coleta amadora e, portanto, não era arqueológico.

Depois de um tempo, fizeram no Museu Histórico Nacional, pretensamente o museu que abriga o discurso da nação, uma espécie de exposição de arqueologia. Pasmem, mas o que está lá, sem nenhuma referência, foi do seu Hildo. Contudo, isso é mesquinharia da ciência e ninguém precisa saber.

Bom, dessa forma, mais ou menos interativa e informal, finalizo a apresentação. Mas isso serve para pensemos em uma frase de Berta Ribeiro (1982), que diz o seguinte: "De que valem coleções etnográficas mal documentadas e mal conservadas, poeirentas, ameaçadas de mofo e infestação de cupim? Como extrair informação científica, cultural e simbólica de objetos mudos, carentes de dados mínimos para subsidiá-los?". Essa é uma questão que não se responde pela Arqueologia, pela Museologia, pela educação, mas pelo alinhado dessas áreas, pensando justamente naquilo que estávamos falando. Nós somos, sobretudo, agentes sociais, e é isso que eu tinha para falar para vocês. Muito obrigado.

\section{BIBLIOGRAFIA INDICATIVA}

BRULON, Bruno. Da artificação do sagrado nos museus: entre o teatro e a sacralidade. An. mus. paul., São Paulo, v. 21, n. 2, p. 155-175, Dec. 2013. Disponível em: $<$ http://www.scielo.br/scielo.php?script=sci_arttext\&pid=S010147142013000200006\&lng=en\&nrm=iso>. Acesso em: 17 nov. 2017. http://dx.doi.org/10.1590/S0101-47142013000200006.

CHAUÍ, Marilena. Nação como Semióforo. Perseu Abramo, 2000.

GOMES, C. R. O Pensamento de Waldisa Rússio Sobre a Museologia. Informação \& Sociedade: Estudos, v. 25, n. 3, 2015. Disponível em: <http://www.brapci.inf.br/v/a/19455>. Acesso em: 17 Nov. 2017. 
GONÇALVES, José Reginaldo Santos. O Espírito e a Matéria: O Patrimônio Enquanto Categoria de Pensamento, DP\&A, 2003.

Ressonância, materialidade e subjetividade: as culturas como patrimônios. Horiz. antropol., Porto Alegre, v. 11, n. 23, p. 15-36, June 2005. Disponível em: http://www.scielo.br/scielo.php?script=sci_arttext\&pid=S010471832005000100002 .

GUARNIERI, Waldisa Rússio Camargo. Alguns aspectos do patrimônio cultural: o patrimônio industrial (1983/1985). In: BRUNO, Maria Cristina Oliveira. (Org.). Waldisa Rússio Camargo Guarnieri: textos e contextos de uma trajetória profissional. v. 1. São Paulo: Pinacoteca do Estado; Secretaria de Estado de Cultura; Comitê Brasileiro do Conselho Internacional de Museus, 2010a. p. 147-159.

HUYSSEN, Andreas. Escapando da amnésia - o museu como cultura de massa. Memórias do modernismo. Rio de Janeiro: Editora da UFRJ, 1996.

Psychology Press, 1995.

Twilight Memories: Marking Time in a Culture of Amnesia,

MOSER, Stephanie. Wondrous Curiosities: Ancient Egypt at the British Museum, University of Chicago Press, 2006.

POMIAN, Krzysztof. Enciclopédia Einaudi, Porto: Imprensa Nacional/Casa da Moeda, 1984.

RENFREW, C.; BAHN, P. Archaeology: Theories, Methods and Practice, Thames \& Hudson, Seventh Edition, 2016.

SHANKS, M.; TILLEY, C. Re-Constructing Archaeology: Theory and Practice, Cup Archive, 1987.

VALÉRY, Paul. Le problème des musées, Paris: Éditions Gallimard, 1960, p. 1290-1293.

BRUNO, Maria Cristina Oliveira. Museus de Arqueologia: uma história de conquistadores, abandono e mudanças. In: Revista do Museu de Arqueologia e Etnologia, n. 6, 1996.

CALDARELLI, S. B. A Arqueologia como Profissão. In: Anais do IX Congresso da Sociedade de Arqueologia Brasileira. Rio de Janeiro: CDRom, 2000.

DIAS, Marjori Pacheco. Novos Métodos Curatoriais Aplicados aos Materiais Arqueológicos da Intervenção ao Acervo. VOL. I, 2013, Santa Maria, RS: Laboratório de Estudos e Pesquisas Arqueológicas Editores. 2014 